\title{
ACID DEPOSITION AND LAKE CHEMISTRY IN SOUTHWEST CHINA
}

\author{
H. B. XUE* \\ Research Center for Eco-Environmental Sciences Academia Sinica, P.O. Box 934, Beijing, PRC \\ and \\ J. L. SCHNOOR \\ Center for Global and Regional Environmental Research and Department of Civil and \\ Environmental Engineering, The University of Iowa, Iowa City, IA S2242, U.S.A.
}

(Received 6 October, 1992; accepted in final form 15 May, 1993)

\begin{abstract}
A water quality survey has been performed on selected lakes and streams in southwest China. The purpose of the study was to measure the concentrations of acidic deposition and surface water chemistry in a region of severe air pollution, forest decline, and relatively sensitive geology to acidic deposition. We show that, although there are some high elevation lakes of low acid neutralizing capacity (ANC $<150 \mu \mathrm{eq} \mathrm{L}^{-1}$ ), acidification of lakes has not occurred in southwest China due to production of base cations in soil and dry deposition of dust that serves to neutralize acidic deposition. Water chemistry is buffered by high base cation concentrations $\left(\mathrm{Ca}^{2+}, \mathrm{Mg}^{2+}, \mathrm{Na}^{+}\right.$, and $\left.\mathrm{K}^{+}\right)$greater than $300 \mu \mathrm{eq} \mathrm{L}^{-1}$, and $\mathrm{pH}$ values are always greater than 6.5 .
\end{abstract}

\section{Introduction}

The provinces of Sichuan and Guizhou in southwest China (Figure 1) were investigated for the chemical effects of air pollution and acidic deposition on lakes and streams (Inst. Environmental Chemistry et al., 1987). Southwest China has a subtropical climate with an average annual temperature of more than $15^{\circ} \mathrm{C}$, and an average precipitation rate of $1000 \mathrm{~mm} \mathrm{yr}^{-1}$. Pollution is great in the large cities of Chongqing in Sichuan Province and Guiyang in Guizhou Province. However, the bedrock of Guizhou Province is mostly limestone $\left(\mathrm{CaCO}_{3}\right)$, and therefore it is not susceptible to acidification of surface waters. The Sichuan Basin occupies one-third of Sichuan Province; it is a large area $\left(200000 \mathrm{~km}^{2}\right)$ with relatively sensitive geology and major industrial cities. Sampling stations identified in Figure 1 that lie in Sichuan Province are located in the Sichuan Basin. The Chongqing area $\left(106^{\circ}-107^{\circ} \mathrm{E}\right.$ long., $28^{\circ}-30^{\circ} \mathrm{N}$ lat.) marks the southeastern border of the Sichuan Basin, and it measures $23000 \mathrm{~km}$ in surface area (Heise, 1988). Forests cover 10.4 percent of the Chongqing area, and 80 percent of the forests are Masson pine (Pinus massoniana Lamb.), ten percent Chinese fir, and ten percent other species. Over 90 percent of the forest has died in the Sichuan Maocaoban Forest (5 $400 \mathrm{ha}$ ). On Nanshan Hill in Chonhqing, an 1800 ha forest of dense Masson pime has lost half of its trees (Heise, 1988).

The bedrock of the Sichuan Basin is Cretaceous beds of red sandstone (quartz, feldspars, and clays), underlain by a Jurassic unit of quartz sandstones and shale,

* Present address: lake Research Lab. of Institute for Water Resources and Water Pollution Control (EAWAG), Swiss Federal Institute of Technology, CH-6047, Kastanienbaum, Switzerland. 


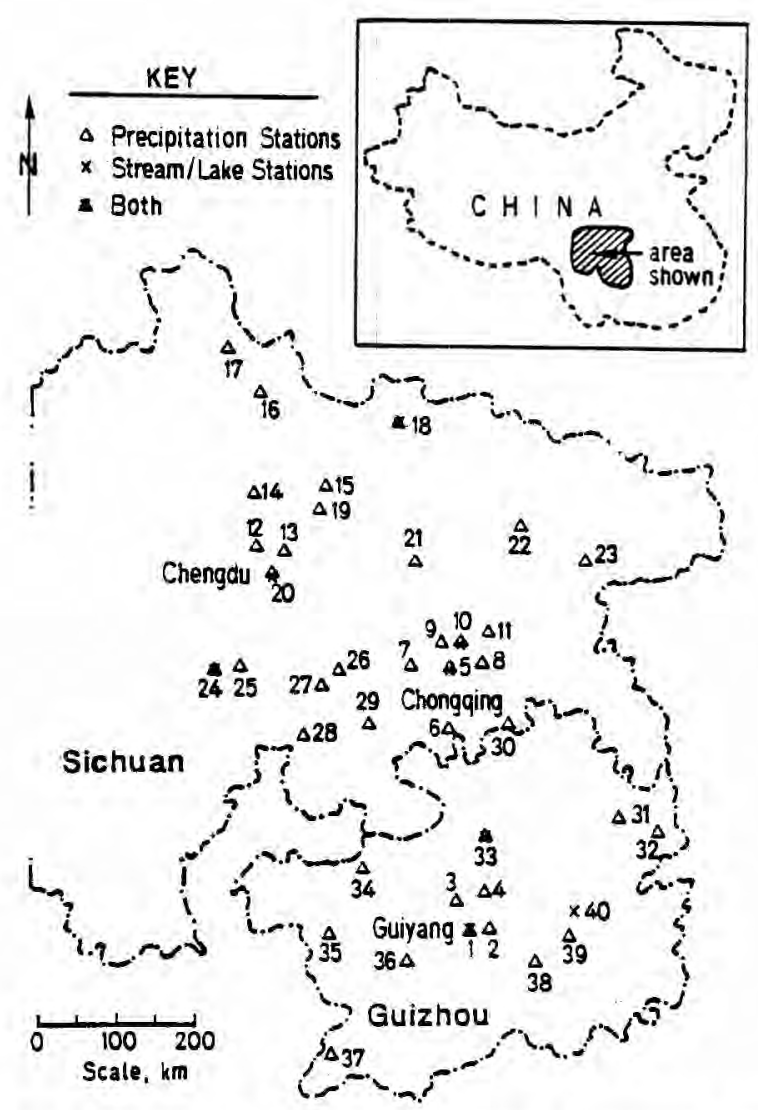

Fig. 1. Site map of study area in southwest China showing precipitation stations and lake/stream sampling stations. Most of the stations in Sichuan that lie west of Chongqing are in the Sichuan Basin of relatively sensitive geology to acidic deposition. Stations in Guizhou.Province are in a limestone area that is generally protected from acidification by acidic deposition. Major cities include Chongqing, Chengdu (the capital of Sichuan Province), and Guiyang (the capital of Guizhou Province). In major cities and a few other locations, there are multiple stream/lake and precipitation stations in urban and suburban locations, as described in Table I. At Emei Mountain (24) and Jinyun Hill (10), there are three stations each, at the top, middle, and bottom elevations.

and further underlain by a Triassic unit of limestone, evaporites, and gypsum. The Triassic limestone outcrops $30-40 \mathrm{~km} \mathrm{~N}$ of Chongqing in an anticline, so windblown calcareous dust exists in the region. The Cretaceous sandstones do not provide much carbonates for rapid neutralization of acidic deposition, but there are other sources of carbonate dust and calcium which are present in the Sichuan Basin including windblown dust from nearby limestone areas, flyash from small furnaces burning coal with a high ash content, and alkaline particles from uncontrolled cement plants emissions. Also, trace amounts of calcite cement in sandstone may provide some small amount of calcium. At Emei Mountain in the western part of 
the study area, the mountain is composed of basalt, crystalline rock that is very slow to weather and neutralize acid deposition.

Coal combustion accounted for more than $70 \%$ of regional energy needs in Sichuan in 1981, and local low-grade coal contains $4-6 \%$ sulfur and $30 \%$ ash. Approximately 5700 tonnes $\mathrm{km}^{-2} \mathrm{yr}^{-1}$ coal are consumed resulting in extremely high $\mathrm{SO}_{2}$ and TSP concentrations in 1985 of $4.4-0.5 \mathrm{mg} \mathrm{m}^{-3}$ and $0.6-0.8 \mathrm{mg} \mathrm{m}^{-3}$, respectively, in Chongqing and Guiyang (Inst. Environmental Chemistry et al., 1988). In the vicinity of the major cities of Sichuan, annual S-deposition is $6.5 \mathrm{~g}$ $\mathrm{m}^{-2} \mathrm{yr}^{-1}$ via dry deposition ( $\mathrm{SO}_{2(g)}$ and aerosol particles), $3.3 \mathrm{~g} \mathrm{~m}^{-2} \mathrm{yr}^{-1}$ in wet precipitation, and $9.8 \mathrm{~g} \mathrm{~m}^{-2} \mathrm{yr}^{-1}$ total. This is approximately 50 percent greater than the highest S-deposition rates reported in regions of Europe and North America (Schnoor and Stumm, 1986; National Academy, 1983). Local airborne particulate concentrations are extremely high, ten times higher than typical ambient air quality standards. (Annual geometric mean TSP concentrations of $0.075 \mathrm{mg} \mathrm{m}^{-3}$ are often adopted as the primary ambient air standard for the protection of human health, Wadden and Scheff, 1983).

\section{Objectives}

The objective of the study is to determine the chemical effects of air pollution and acid deposition on surface waters in Southwest China, an area of extremely high sulfur dioxide and particulate air pollution. In particular, we seek to determine if acidification of surface waters has occurred as a result of high wet sulfate concentrations in precipitation. The research focuses on the reactions that determine surface water chemistry in a region receiving high atmospheric deposition and on assessing the sensitivity of lakes to future acidic deposition.

\section{Methods}

A description of the sampling stations is presented in Table $I$, and the station numbers are located in Figure 1. Precipitation stations were chosen on the basis of (1) urban sites of known high air pollution emissions, (2) suburb or rural sites as references of intermediate pollution and (3) mountain stations to provide a background estimate of relatively unpolluted areas. All precipitation monitoring stations required a power souce for operation of the wet-dry collectors, sulfur dioxide monitors and hi-volume particulate filters. Lake and stream monitoring stations were co-located with the precipitation stations. They were chosen at Chongqing, Guongyang and Guiyang to measure the effect of major urban emission sources. The station at Chongqing was located at Nanshan Hill because this is an area of dramatic forest decline. At Changshou, Zunyi, and Taijiang, the stream/lake stations were chosen to represent a more moderate level of pollution and characteristic of the rural environment. The station at Emei Mountain was chosen as a reference of high elevation and with few emission sources. 


\section{TABLE I}

Description of the sampling stations for precipitation and lakewater in southwest China

\begin{tabular}{|c|c|c|}
\hline Station no. & Location & Remarks \\
\hline & Guiyang & $\begin{array}{l}3 \text { in urban, } 2 \text { in suburb for precipitation, } 1 \text { in urban, } \\
3 \text { in suburb for stream/lake }\end{array}$ \\
\hline 2 & $\begin{array}{l}\text { Shisun } \\
\text { Yunwu mountain } \\
\text { Kaiyang }\end{array}$ & \\
\hline \multirow[t]{4}{*}{5} & Chongqing & $\begin{array}{l}3 \text { in urban, } 2 \text { in suburb for precipitation, } 1 \text { in urban, } \\
1 \text { in suburb for stream/lake }\end{array}$ \\
\hline & Nantong & \\
\hline & Dazu & \\
\hline & Changshou & 2 for stream/lake \\
\hline \multirow[t]{2}{*}{9} & Hushi & \\
\hline & Beipei and Jinyun Hill & $\begin{array}{l}\text { at top, middle and bottom respectively for stream/lake } \\
\text { sites on the hill, precipitation in Beipei }\end{array}$ \\
\hline 11 & Huayun & \\
\hline 12 & Pengxian & \\
\hline 13 & maowen & \\
\hline 14 & Guanghan & \\
\hline 15 & Jiangyou & \\
\hline 16 & Huanglongsi & \\
\hline 17 & Jiuzaigou & \\
\hline 18 & Guongyang & $\begin{array}{l}1 \text { in urban, } 2 \text { in suburb for precipitation, } 2 \text { in urban, } \\
2 \text { in suburb for stream/lake }\end{array}$ \\
\hline 19 & Mianyian & \\
\hline 20 & Chengdu & $\begin{array}{l}2 \text { in urban, } 2 \text { in suburb for precipitation, } \\
2 \text { in suburb for stream/lake }\end{array}$ \\
\hline 21 & Nanchong & \\
\hline 22 & Daxian & \\
\hline 23 & Wanxian & \\
\hline 24 & Emei mountain & at top, middle and bottom respectively for stream/lake \\
\hline 25 & Leshan & \\
\hline 26 & Neijiang & \\
\hline 27 & Zigong & \\
\hline 28 & Yibin & \\
\hline 29 & Luzhou & \\
\hline 30 & Jinfo mountain & \\
\hline 31 & Fanjing mountain & \\
\hline 32 & Tongren & \\
\hline 33 & Zunyi & 1 in urban, 1 in suburb for stream/lake \\
\hline 34 & Bijie & \\
\hline 35 & Shuicheng & \\
\hline 36 & Anshun & \\
\hline 37 & Xingyi & \\
\hline 38 & Duyun & \\
\hline 39 & Kaili & \\
\hline 40 & Taijiang & only 1 for stream/lake for precipitation \\
\hline
\end{tabular}

* All locations other than Taijiang No. 40, have stations for precipitation.

In locations listed without remarks, there are no stations for stream/lake sampling. 


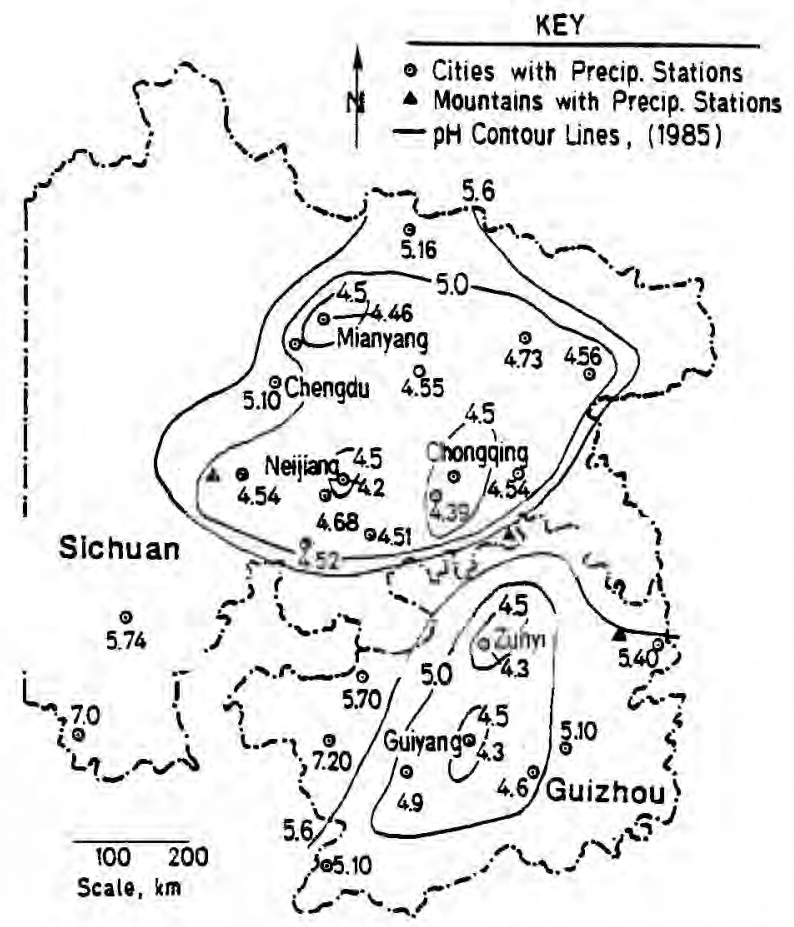

Fig. 2. (A) Volume-weighted average $\mathrm{pH}$ contours for precipitation. The $\mathrm{pH}$ contour lines were drawn by interpolation of data at all stations. $\mathrm{pH}$ values at individual stations for the period 1982-86 are also shown. A few stations were located at mountainous sites distant from local sources. (Modified from ref. Inst. Environ. Chęm., 1987).

Precipitation samples were collected by grab samples during rain storms, in some cases in automatic wet-dry bucket devices from 1982-86. Lakes and streams were sampled just below the surface four times during the study period of July 1987-October 1988. Cation analyses were performed using ICP (Inductively Coupled Plasma emission spectrometry), and anions were analyzed with an IC (Ion Chromatograph, Dionex ${ }^{R}$ ) at the Research Center for Eco-Environmental Sciences in Beijing. Acid neutralizing capacity was measured by inflection point titration using a Metrohm 665 Dosimat with 682 Titroprocessor. Cation concentrations determined by ICP were corrected from total dissolved to free metal ions using the modified equilibrium speciation program REDEQL-II (Morel and Morgen, 1972; Xue et al., 1988). Corrections were on the order of $10-15 \%$ of measured values. Ion balances were within ten percent in most cases with a tendency for a deficit of anions in precipitation samples and surface water samples. Dissolved organic carbon concentrations correlated with the anion deficit. 


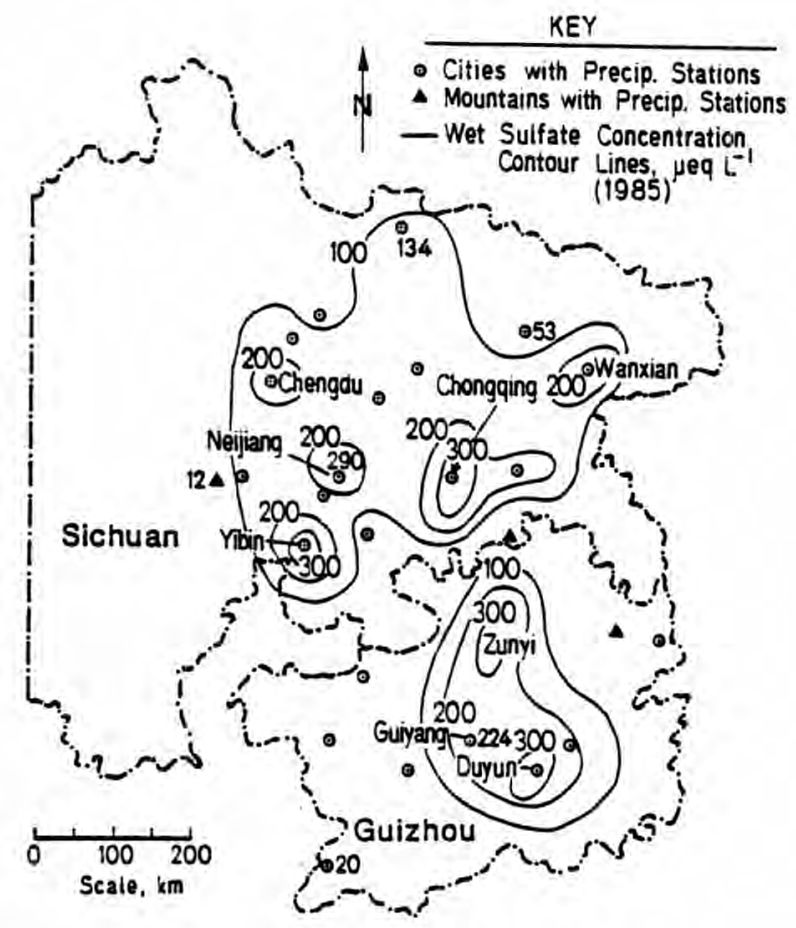

Fig. 2. (B) Volume-weighted average sulfate concentrations in precipitation samples and sulfate contour lines in ueq $\mathrm{L}^{-1}$. Contours show the distinct local nature of the pollution near major cities where coal is combusted. (Modified from ref. Inst. Environ. Chem., 1987).

\section{Results and Discussion}

Figure $2 \mathrm{~A}$ shows the annual volume-weighted average $\mathrm{pH}$ of precipitation contours from samples taken in 1985 at various stations. Pollution was evident in the vicinity of major cities. The lowest annual average $\mathrm{pH}$ values measured were 4.3, a moderate level of acidity corresponding to the $\mathrm{pH}$ of precipitation in broad regions of Central Europe and northeastern United States. It is less acidic than the most polluted areas in Europe (Central Germany, Poland, and Czechoslovakia) and the U.S. (southern New York and eastern Pennsylvania, New Jersey, and Maryland) (Natural Resources Ecology Lab., 1986; Rubin et al., 1992).

Figure $2 \mathrm{~B}$ shows high concentrations of sulfate ions in precipitation that were measured in southwest China. A myriad of local sources contribute to the regional air pollution. Concentrations in excess of $200 \mu \mathrm{eq} \mathrm{L}-1$ have not been reported in Europe or North America except near local sources. Major ion chemistry of precipitation is reported for selected stations for 1982-86 (Table IIA). The greatest acidity $\left(\mathrm{H}^{+}\right.$activity) and sulfate concentrations were in samples collected near the cities of Guiyang, Chongqing, and Neijiang. Calcium was the major cation in precipitation, followed by ammonium. Sulfate was by far the dominant anion in 


\section{TABLE IIA}

Precipitation chemistry at stations in southwest China, 1982-86

\begin{tabular}{|c|c|c|c|c|c|c|c|c|c|c|c|c|}
\hline $\begin{array}{l}\text { Station } \\
\text { no. }\end{array}$ & Location & Description & $\begin{array}{l}\mathrm{Ca}^{++} \\
\mu \mathrm{eq} \mathbf{L}^{-1}\end{array}$ & $\begin{array}{l}\mathrm{Mg}^{++} \\
\mu \text { eq } \mathrm{L}^{-1}\end{array}$ & $\begin{array}{l}\mathrm{Na}^{+} \\
\mu \mathrm{eq} \mathrm{L}^{-1}\end{array}$ & $\begin{array}{l}\mathrm{K}^{+} \\
\mu \text { eq } \mathrm{L}^{-1}\end{array}$ & $\begin{array}{l}\mathrm{NH}_{4}{ }^{+} \\
\mu \text { eq } \mathrm{L}^{-1}\end{array}$ & $\begin{array}{l}\mathbf{H}^{+} \\
\mu e q \mathbf{L}^{-1}\end{array}$ & $\begin{array}{l}\mathrm{SO}_{4}^{--} \\
\mu e q \mathrm{~L}^{-1}\end{array}$ & $\begin{array}{l}\mathrm{Cl}^{-} \\
\mu \mathrm{eq} \mathrm{L}^{-1}\end{array}$ & $\begin{array}{l}\mathrm{NO}_{3}^{-} \\
\mu e q \mathrm{~L}^{-1}\end{array}$ & $\begin{array}{l}\mathrm{F}^{-} \\
\mu \mathrm{eq} \mathrm{L}^{-1}\end{array}$ \\
\hline \multirow[t]{2}{*}{1} & Guiyang & A-urban & 231 & 57 & 10 & 26 & 79 & 85 & 411 & 8 & 21 & 18 \\
\hline & & & 198 & 45 & 11 & 11 & 49 & 38 & 281 & 12 & 25 & 11 \\
\hline 4 & Kaiyang & A-suburb & 88 & 29 & 6 & 7 & 51 & 26 & 167 & 21 & 16 & 6 \\
\hline \multirow[t]{3}{*}{5} & Chongqing & A-urban & 187 & 26 & 14 & 17 & 126 & 72 & 387 & 26 & 27 & 18 \\
\hline & & B-urban & 170 & 23 & 15 & 8 & 152 & 51 & 328 & 25 & 30 & 22 \\
\hline & & C-suburb & 125 & 18 & 13 & 15 & 136 & 33 & 228 & 19 & 26 & 31 \\
\hline 18 & Guongyang & & 220 & 36 & 49 & 26 & 67 & 1.4 & 134 & 33 & 19 & 7 \\
\hline 24 & Emei Mountain & & 30 & 4 & 14 & 12 & 33 & 29 & 36 & 17 & 5 & 2 \\
\hline 26 & Neijiang & & 220 & 24 & 33 & 38 & 170 & 140 & 290 & 30 & 37 & 6 \\
\hline 27 & Zigong & & 290 & 24 & 17 & 6 & 83 & 14 & 170 & 46 & 8 & 3 \\
\hline 28 & Yibin & & 175 & 53 & 103 & 28 & 166 & 45 & 300 & 57 & 24 & 44 \\
\hline
\end{tabular}




\section{TABLE IIB}

Water chemistry of lakes/streams in southwest China, 1987-88

\begin{tabular}{|c|c|c|c|c|c|c|c|c|c|c|c|c|c|}
\hline $\begin{array}{l}\text { Station } \\
\text { no. }\end{array}$ & Location & Description & $\begin{array}{l}\mathrm{Ca}^{++} \\
\mu e q \mathrm{~L}^{-1}\end{array}$ & $\begin{array}{l}\mathrm{Mg}^{++} \\
\mu e q \mathrm{~L}^{-1}\end{array}$ & $\begin{array}{l}\mathrm{Na}^{+} \\
\mu \mathrm{eq} \mathrm{L}^{-1}\end{array}$ & $\begin{array}{l}\mathrm{K}^{+} \\
\mu \mathrm{eq} \mathrm{L}^{-1}\end{array}$ & $\begin{array}{l}\mathrm{SO}_{4}^{--} \\
\mu e q \mathrm{~L}^{-1}\end{array}$ & $\begin{array}{l}\mathrm{NO}_{3}^{-} \\
\mu \mathrm{eq} \mathrm{L}^{-1}\end{array}$ & $\begin{array}{l}\mathrm{Cl}^{-} \\
\text {неq } \mathrm{L}^{-1}\end{array}$ & $\begin{array}{l}\mathrm{F}^{-} \\
\mu e q \mathrm{~L}^{-1}\end{array}$ & $\mathrm{pH}$ & $\begin{array}{l}\text { ANC } \\
\mu e q L^{-1}\end{array}$ & $\begin{array}{l}\text { DOC } \\
\mathrm{mg} \mathrm{L}^{-1}\end{array}$ \\
\hline & Guiyang & A-lake & & & 115 & 93 & 1228 & 26 & & 2.6 & 8.43 & 2409 & \\
\hline & & B-lake & & & 77 & 108 & 1209 & 83 & & 0.0 & 7.86 & 3359 & \\
\hline & & C-lake & & & 86 & 110 & 1027 & 297 & & 10.0 & 8.20 & 2402 & \\
\hline \multirow[t]{2}{*}{5} & Chongqing & A-lake & & & 855 & 115 & 1934 & 17 & & 16.3 & 8.46 & 2026 & \\
\hline & & B-lake, Nanshan & & & 205 & 118 & 979 & 86 & & 0.0 & 6.79 & 822 & \\
\hline 8 & Changshou & A-lake & & & 283 & 88 & 583 & 51 & & 0.0 & 7.95 & 2384 & \\
\hline \multirow[t]{2}{*}{10} & Jinyu hill & A-lake, top & & & 42 & 76 & 307 & 165 & & 0.0 & 6.65 & 146 & \\
\hline & & B-lake, mid. & & & 65 & 81 & 249 & 0 & & 0.0 & 6.63 & 167 & \\
\hline \multirow[t]{2}{*}{20} & Chengdu & A-lake & & & 138 & 121 & 778 & 34 & & 24.7 & 7.88 & 1623 & \\
\hline & & B-lake & & & 199 & 102 & 424 & 17 & & 12.1 & 7.90 & 1345 & \\
\hline \multirow[t]{3}{*}{24} & Emei mountain & A-pool, $3070 \mathrm{~m}$ & & & 33 & 58 & 82 & 13 & & 0.0 & 6.53 & 296 & \\
\hline & & B-stream, $1600 \mathrm{~m}$ & & & 18 & 49 & 549 & 100 & & 0.0 & 6.93 & 1584 & \\
\hline & & C-lake, $500 \mathrm{~m}$ & & & 137 & 27 & 1446 & 23 & & 0.0 & 8.01 & 1425 & \\
\hline \multirow[t]{2}{*}{33} & Zunyl & A-lake & & & 126 & 88 & 1515 & 0 & & 5.3 & 8.30 & 1937 & \\
\hline & & B-river & & & 114 & 77 & 1082 & 114 & & 0.0 & 8.15 & 2613 & \\
\hline 40 & Taijlang & A-stream & & & 187 & 54 & 103 & 17 & & 0.0 & 6.88 & 369 & \\
\hline
\end{tabular}


precipitation, emanating from $\mathrm{SO}_{2}$ oxidation. The most dilute precipitation samples came from Emei Mountain station in the southwestern portion of Sichuan Basin at an elevation of $3070 \mathrm{~m}$. Samples at Emei Mountain contained much lower levels of sulfate in precipitation. Table IIA does not include organic acid anions which explain a large part of the anion deficit.

Water chemistry for selected lakes and streams in southwest China is presented in Table IIB. ANC may be considered as an anion in Table IIB, and the titration would have included both bicarbonate and organic acid anions. Surface waters in areas of limestone terrain (including Changsou in the Sichuan Basin, and Guiyang and Zunyi in Guizhou Province) has the highest calcium concentrations, greater than $2000 \mu \mathrm{eq} \mathrm{L}-1$. Lakes located near big cities with local sources of pollution had high concentrations (but lower than lakes in limestone terrain, e.g. Chongqing and Chengdu). High-elevation lakes had the lowest calcium and ANC concentrations (Jinyu Hill, top of Emei Mountain, and Taijiang). Lakes and streams with the lowest ANC concentrations $\left(150-400 \mu \mathrm{eq} \mathrm{L}^{-1}\right)$ in this survey were, nevertheless, sufficiently buffered to be protected from acidification by acidic deposition. Acidity of precipitation would have to increase by $50 \mu \mathrm{eq} \mathrm{L} \mathrm{L}^{-1}$, and it would need to be further concentrated three-fold by evapoconcentration in order to consume 150 $\mu \mathrm{eq} \mathrm{L}^{-1}$ of ANC existing in these systems (Schnoor and Stumm, 1986). Thus, this survey did not discover any surface waters that have been acidified ( $\mathrm{ANC}<50$ ueq $\mathrm{L}^{-1}$ ) nor any that are in immediate danger.

A comparison between precipitation chemistry and lake chemistry stations from throughout selected areas of the world affected by acidic precipitation is shown in Table III. The high-elevation precipitation station at Emei Mountain was most comparable to the station in the Adirondack Park of New York of the National Atmospheric Deposition Program (NADP), especially for sulfate and $\mathrm{pH}$. However, the station at Emei Mountain, China, showed a greater sea salt contribution $(\mathrm{NaCl})$ and more calcium and potassium in precipitation. Calcium in precipitation samples indicates neutralization of $\mathrm{H}_{2} \mathrm{SO}_{4}$ in 'acid rain' by $\mathrm{CaCO}_{3}$-dust, or, equivalently, the dissolution of neutral gypsum dust $\left(\mathrm{CaSO}_{4}\right)$.

Of the sites examined in the more polluted areas of Guiyang, most were comparable to a high-deposition site near Göttingen, FRG (Solling). Guiyang and Chongqing had somewhat higher sulfate concentrations than Solling in Table IIIA, but these were more than compensated by elevated calcium concentrations, resulting in a higher $\mathrm{pH}$ of precipitation in China ( $\mathrm{pH} 4.4-4.5)$ compared to Solling $(\mathrm{pH}$ 4.05). Ammonium concentrations at Chongquing $\left(136 \mu \mathrm{eq} \mathrm{L} \mathrm{L}^{-1}\right)$ were elevated compared to Solling ( $94 \mu \mathrm{eq} \mathrm{L}^{-1}$ ). Absorption and dissolution of ammonia in the atmosphere serves to neutralize acid precipitation (Stumm et al., 1987). High concentrations of ammonium ions in precipitation at Chongqing were similar to those reported in the Netherlands where animal husbandry and agriculture are large anthropogenic contributors of $\mathrm{NH}_{3(g)}$ (Van Breeman et al., 1982).

Table IIIB shows the chemical characteristics of lakes in some areas of the world affected by acidic deposition. Lakes shown in the U.S., Norway, and Switzerland 


\section{TABLE IIIA}

Comparison of precipitation chemistry (volume-wtd. average) at sites affected by acid deposition

\begin{tabular}{|c|c|c|c|c|c|c|c|c|c|c|c|c|c|}
\hline No. & Location & $\begin{array}{l}\mathrm{Ca}^{++} \\
\mu \mathrm{eq} \mathrm{L}^{-1}\end{array}$ & $\begin{array}{l}\mathrm{Mg}^{++} \\
\mu \mathrm{eq} \mathrm{L}^{-1}\end{array}$ & $\begin{array}{l}\mathrm{Na}^{+} \\
\mu e q \mathrm{~L}^{-1}\end{array}$ & $\begin{array}{l}\mathrm{K}^{+} \\
\mu \mathrm{eq} \mathrm{L}^{-1}\end{array}$ & $\begin{array}{l}\mathrm{NH}_{4}{ }^{+} \\
\mu e q \mathrm{~L}^{-1}\end{array}$ & $\begin{array}{l}\mathrm{H}^{+} \\
\mu \mathrm{eq} \mathrm{L^{-1 }}\end{array}$ & $\begin{array}{l}\mathrm{SO}_{4}-- \\
\mu e q L^{-1}\end{array}$ & $\begin{array}{l}\mathrm{Cl}^{-} \\
\mu \mathrm{eq} \mathrm{L}^{-1}\end{array}$ & $\begin{array}{l}\mathrm{NO}_{3}^{-} \\
\mu \text { eq } \mathrm{L}^{-1}\end{array}$ & $\mathrm{pH}$ & Year & Ref. \\
\hline & $\begin{array}{l}\text { Adirondacks } \\
\text { (N.Y.) U.S. }\end{array}$ & 5 & 2 & & 0.5 & 10 & 38 & 37 & 3 & 20 & 4.4 & 1984 & $\begin{array}{l}\text { Lee and } \\
\text { Schnoor, } 1988\end{array}$ \\
\hline 2 & $\begin{array}{l}\text { Southern Blue } \\
\text { Ridge, U.S. }\end{array}$ & 7 & 2 & 4 & 0.4 & 10 & 26 & 32 & 6 & 13 & 4.6 & 1984 & $\begin{array}{l}\text { Lee and } \\
\text { Schnoor, } 1988\end{array}$ \\
\hline 3 & $\begin{array}{l}\text { Cristallina, } \\
\text { Switzerland }\end{array}$ & 19 & 2 & 3 & 2 & 10 & 11 & 31 & 5 & 11 & 5.0 & 1985 & $\begin{array}{l}\text { Giovanoli } \\
\text { et al., } 1988\end{array}$ \\
\hline 4 & Solling, FRG & 39 & 11 & 38 & 12 & 94 & 90 & 172 & 53 & 68 & 4.05 & $1968-74$ & $\begin{array}{l}\text { Ulrich } e t \text {, } \\
\text { al., } 1979\end{array}$ \\
\hline 6 & $\begin{array}{l}\text { Emei mountain, } \\
\text { PRC }\end{array}$ & 30 & 4 & 14 & 12 & 33 & 29 & 36 & 17 & 5 & 4.5 & 1985 & $\begin{array}{l}\text { Inst.Env.Chem. } \\
\text { et al., } 1987\end{array}$ \\
\hline 4 & $\begin{array}{l}\text { Guiyang } \\
\text { suburb, PRC }\end{array}$ & 198 & 45 & 11 & 11 & 49 & 38 & 281 & 12 & 25 & 4.4 & $1982-84$ & ditto \\
\hline 5 & $\begin{array}{l}\text { Chongqing } \\
\text { suburb, PRC }\end{array}$ & 125 & 18 & 13 & 15 & 136 & 33 & 228 & 19 & 26 & 4.5 & $1985-86$ & ditto \\
\hline
\end{tabular}


are in relatively remote regions, not directly affected by waste discharges, but receiving long-range transported acidic deposition. Lakes near the top of Emei Mountain and Jinyu Hill PRC are similar in chemistry to the lakes in New York and Pennsylvania (Pocono and Catskill Mountains) of Table IIIB. These lakes receive a high concentration of sulfate in precipitation and dry deposition, and sulfate is concentrated by evapotranspiration. The climate is similar to the Southern Blue Ridge in the U.S., where there is an annual mean evapoconcentration factor of 2.8 (Lee and Schnoor, 1988). Chemistries of the river at Guiyang and the lake on Nanshan Hill near Chongqing are dominated by calcium, sulfate, and bicarbonate ions. Calcium comes from wet precipitation, dry deposition, and production in the watershed by ion exchange and chemical weathering. Production of calcium in the watershed in the largest contribution for those lakes where calcite is present and calcium ion concentrations are very large $\left(>1000 \mu \mathrm{eq} \mathrm{L}{ }^{-1}\right)$. Sulfate comes from wet precipitation and dry deposition of $\mathrm{SO}_{2}$ and sulfate particles (Inst. Environmental Chemistry et al., 1987). Dry deposition of $\mathrm{SO}_{2}$ and sulfate are aided by efficient collection in forest canopies (Lingerg et al., 1986; Lindberg and Garten, 1988), but the Masson pine forest at the top of Nanshan Hill is dying. Symptoms are most consistent with a direct effect of $\mathrm{SO}_{2}$ (Blank, 1985; Blank et al., 1988). $\mathrm{SO}_{2}$ gas concentrations in Chongqing of $0.51 \mathrm{mg} \mathrm{m}^{-3}$ are more than 40 times greater than those measured in the Bavarian and Black Forests of Germany of 0.004$0.014 \mathrm{mg} \mathrm{m}^{-3}$ (Blank, 1985; Blank et al., 1988), and five times greater than those reported in the most polluted region of Czechoslovakia of $0.1 \mathrm{mg} \mathrm{m}^{-3}$ (Moldan and Schnoor, 1992). Bicarbonate ions in lake waters come from neutralization reactions of ion exchange and chemical weathering, also producing $\mathrm{Ca}^{2+}$ and $\mathrm{Mg}^{2+}$ ions. Potassium ions in southwest China surface waters were very large compared to lakes in other countries (Table IIIB). The source of these potassium ions is not known.

The precipitation chemistry and lake chemistry for the Chongqing area and Nanshan Hill in Sichuan Province are shown in Figure 3A. Precipitation is acidic with an annual volume-weighted $\mathrm{pH}$ of 4.29 in 1982-1986. It is composed primarily of $\mathrm{CaSO}_{4}(\mathrm{aq})$ and $\left(\mathrm{NH}_{4}\right)_{2} \mathrm{SO}_{4}(\mathrm{aq})$ with small amounts of other cations $\left(\mathrm{K}^{+}\right.$, $\mathrm{H}^{+}, \mathrm{Mg}^{2+}$, and $\left.\mathrm{Na}^{+}\right)$and anions $\left(\mathrm{Cl}^{-}, \mathrm{NO}_{3}{ }^{-}\right.$, and $\left.\mathrm{F}^{-}\right)$. Annual mean precipitation is concentrated about 3.0 times by evapotranspiration, based on sulfate as a conservative anion, and this agrees with measurements in the southeastern U.S. with similar climatology (Lee and Schnoor, 1988). Table IVA shows a mass balance, a proposed reaction sequence that would explain the chemical composition of the lake on Nanshan Hill, Chongqing, based on measured ion concentrations in precipitation and surface water. These is a considerable amount of dry deposition that explains the sulfate chemistry of the lake, and it is consistent with large amounts of dry deposition with high concentrations of soluble calcium and sulfate $(\sim 0.4$ $\mu$ eq $\mathrm{m}^{-3}$, Chongqing) in the airborne particulate matter that were measured (Inst. Environmental Chemistry et al., 1987). This dry deposition is in the form of $\mathrm{CaSO}_{4}$ which comes from the reactions of calcareous dust $\left(\mathrm{CaCO}_{3}\right)$ with $\mathrm{H}_{2} \mathrm{SO}_{4}$ from $\mathrm{SO}_{2}$ 


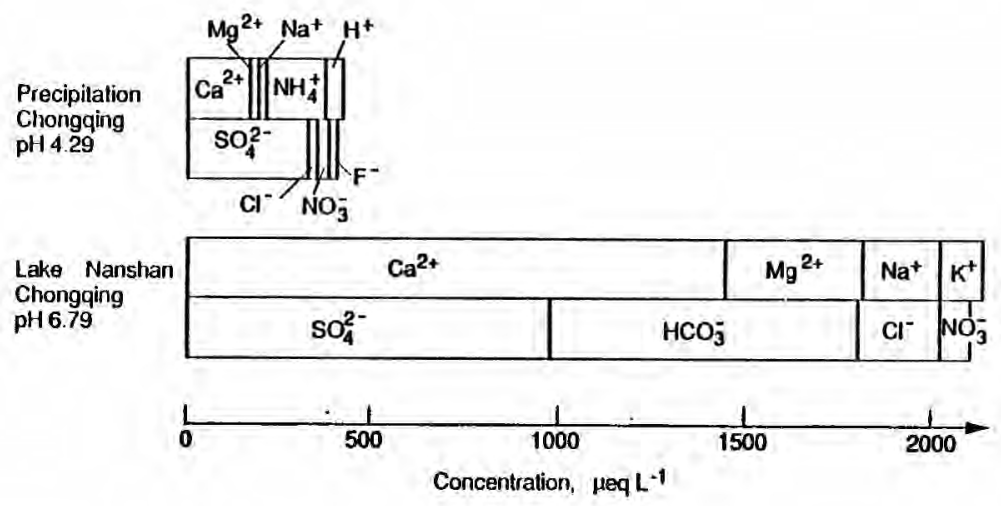

Fig. 3. (A) Bar diagram for precipitation chemistry and lake chemistry at the Lake near Nanshan Hill, Chongqing.

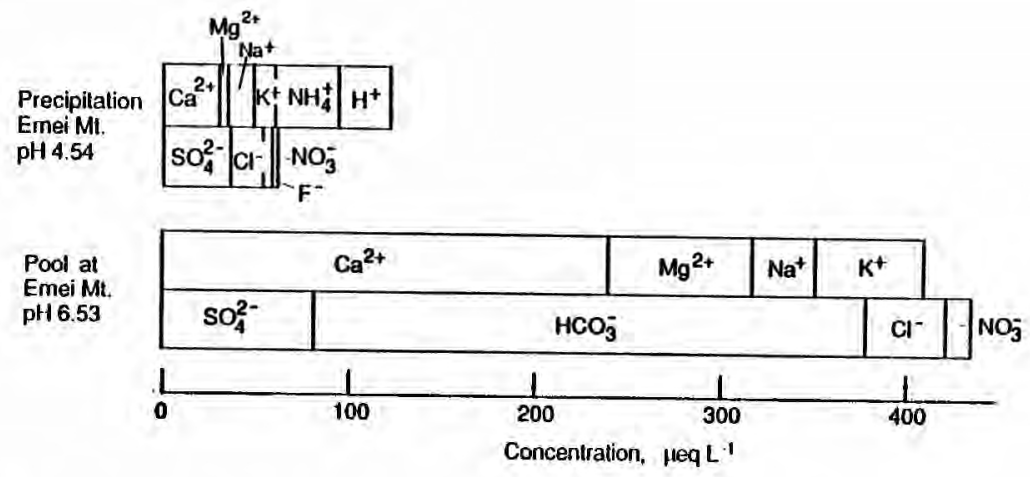

Fig. 3. (B) Bar diagram for precipitation chemistry and pool chemistry at Emei Mountain, elevation $3070 \mathrm{~m}$.

oxidation in the atmosphere. There is no net effect on the acidity of deposition however. Due to the abundance of base cations in the-Basin, a number of reactions take place to neutralize acid deposition including ion exchange and weathering reactions in the terrestrial environment. In addition, $\mathrm{NH}_{4}{ }^{+}$is assimilated by plants and algae in the catchment area, resulting in a consumption of alkalinity:

$$
\mathrm{NH}_{4}^{+}+4 \mathrm{CO}_{2}+\mathrm{HCO}_{3}^{-}+\mathrm{H}_{2} \mathrm{O}=\mathrm{C}_{5} \mathrm{H}_{7} \mathrm{NO}_{2}+5 \mathrm{O}_{2} \text {. }
$$

The net result of all these reactions is a circumneutral lake with a pH of near 7 and an acid neutralizing capacity of $822 \mu \mathrm{eq} \mathrm{L}^{-1}$. The reactions and evapoconcentration factor were not measured directly, however, there is a good agreement between 


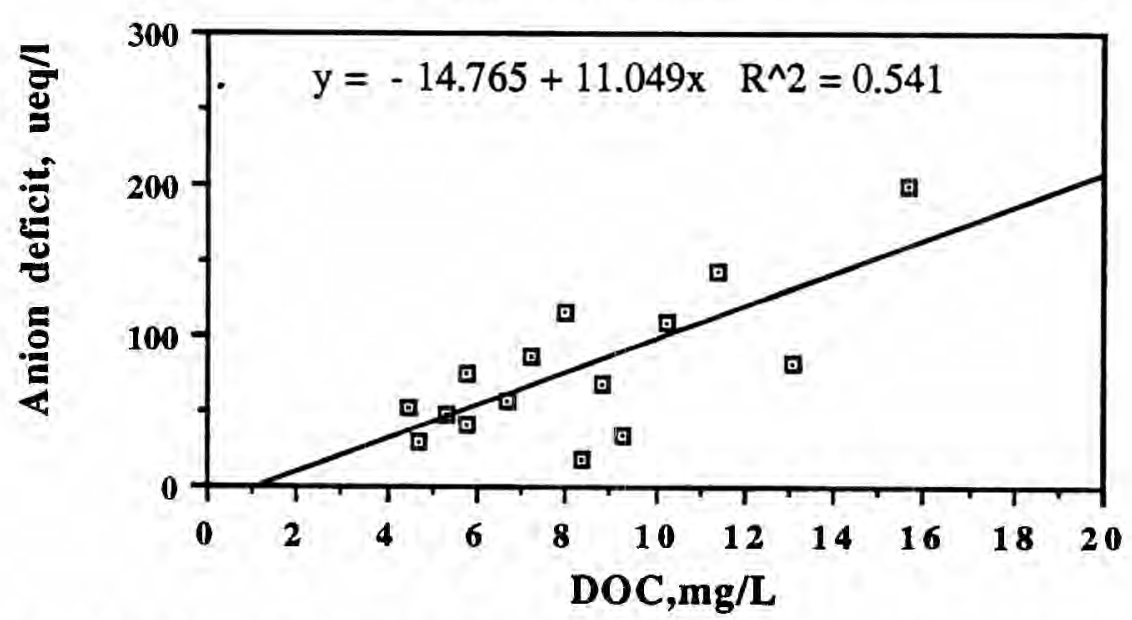

Fig. 4. Effect of Dissolved Organic Carbon concentrations on the measured anion deficit (sum of cation equivalents minus anion equivalents) among all the stations listed in Table I.

the calculated and measured lake chemistry of Table IVA. The measured acid neutralizing capacity (titration ANC) provides a check on the summation of dry deposition and reactions in the watershed (Table IVA).

The chemistry of both precipitation and surface waters is much more dilute at Emei Mountain (Figure 2B) because it does not receive local pollution but only long range transport of pollutants. Emei Mountain is forested so there is a large discrepancy (anion deficiency) in the sum of the measured cations versus the sum of the measured anions in precipitation. This can be attributed to short chain acids (especially acetic and formic acids have been measured) which are the decomposition products of alcohols, ketones, and terpenes given off by vegetation. These organics are oxidized in the terrestrial/aquatic system or else they remain in the surface water and can be measured as DOC. Figure 4 illustrates the strong correlation between DOC and anion deficit in the samples. A portion of the organic anions in surface waters may be included in an ANC determination. The portion of the bar diagram marked $\mathrm{HCO}_{3}-$ in Figure $3 \mathrm{~B}$ is really both bicarbonate alkalinity and some contribution of ANC from organic acid anions.

Table IVB is the proposed reaction sequence for the chemistry of the pool at Emei Mountain. There was little dry deposition measured or sea salt influence at $3070 \mathrm{~m}$ elevation. The dominant reactions that occur in the terrestrial and aquatic ecosystems are $\mathrm{NH}_{4}{ }^{+}$uptake by plants and exchange/weathering to yield cations. On the basis of these simple reaction mechanisms, the chemical composition of the pool at Emei Mountain can be estimated. The titration ANC that is calculated includes the contribution from organics. The calculated pool chemistry agrees quite well with the measured chemistry in Table IVB.

It can be seen from Table IVB that hydrogen ion deposition would need to increase by three fold (to $196 \mu \mathrm{eq} \mathrm{L}{ }^{-1}$ ) to cause the pool at Emei Mountain to 
TABLE IVA

Proposed reaction sequence to establish the chemical composition of Lake Nanshan, near Chongqing, China (all concentrations expressed in $\mu \mathrm{eq} \mathrm{L}^{-1}$ )

\begin{tabular}{|c|c|c|c|c|c|c|c|c|c|c|}
\hline & $\mathbf{H}^{+}$ & $\mathrm{Ca}^{++}$ & $\mathrm{Mg}^{++}$ & $\mathrm{Na}^{+}$ & $\mathrm{K}^{+}$ & $\mathrm{NH}_{4}{ }^{+}$ & $\mathrm{SO}_{4}^{--}$ & $\mathrm{Cl}^{-}$ & $\mathrm{NO}_{3}^{-}$ & $\mathrm{F}^{-}$ \\
\hline \multicolumn{11}{|l|}{ Atmospheric deposition } \\
\hline $\begin{array}{l}\text { Chongqing precipitation } \\
\text { (after evapotranspiration) }\end{array}$ & 99 & 375 & 54 & 39 & 45 & 408 & 684 & 57 & 78 & 45 \\
\hline $\begin{array}{l}\text { Dry deposition } \\
\left(\mathrm{CaCO}_{3}+\mathrm{H}_{2} \mathrm{SO}_{4}\right)\end{array}$ & & 295 & & & & & 295 & & & \\
\hline Dust + Seal salt, $\mathrm{NaCl}$ & & & & 159 & & & & 159 & & \\
\hline Total to lake & 99 & 670 & 54 & 198 & 45 & 408 & 979 & 216 & 78 & 45 \\
\hline \multicolumn{11}{|l|}{ Rxns. in watershed } \\
\hline $\mathrm{NH}_{4}{ }^{+}$assimilation & 408 & & & & & -408 & & & & \\
\hline $\begin{array}{l}\text { Exchange/weathering } \\
\left(\mathrm{CaCO}_{3}, \mathrm{MgCO}_{3}, \mathrm{~K}_{2} \mathrm{CO}_{3}\right)\end{array}$ & -1163 & 780 & 310 & & 73 & & & & & \\
\hline $\begin{array}{l}\text { Total lake composition } \\
\text { (calculated) }\end{array}$ & -656 & 1450 & 364 & 198 & 118 & 0 & 979 & 216 & 78 & 45 \\
\hline $\begin{array}{l}\text { Lake composition } \\
\text { (measured) }\end{array}$ & $-822^{a}$ & 1450 & 364 & 205 & 118 & 0 & 979 & 216 & 86 & \\
\hline
\end{tabular}

${ }^{a} \mathrm{ANC}=-\left\{\mathrm{H}^{+}-\mathrm{acy}\right\}$. 


\section{TABLE IVB}

Proposed reaction sequence to establish the chemical composition of the pool at Emei Mountain (all concentrations in $\mu \mathrm{eq} \mathrm{L}^{-1}$ )

\begin{tabular}{|c|c|c|c|c|c|c|c|c|c|c|c|}
\hline & $\mathbf{H}^{+}$ & $\mathrm{Ca}^{++}$ & $\mathrm{Mg}^{++}$ & $\mathrm{Na}^{+}$ & $\mathbf{K}^{+}$ & $\mathrm{NH}_{4}{ }^{+}$ & $\mathrm{SO}_{4}^{--}$ & $\mathrm{Cl}^{-}$ & $\mathrm{NO}_{3}-$ & $\mathbf{F}^{-}$ & $\mathrm{Org}^{-}$ \\
\hline \multicolumn{12}{|l|}{ Atmospheric deposition } \\
\hline $\begin{array}{l}\text { Emei precipitation } \\
\text { (after evapotranspiration) }\end{array}$ & 66 & 68 & 9 & 32 & 27 & 75 & 82 & 39 & 11 & 15 & 130 \\
\hline \multicolumn{12}{|l|}{ Rxns. in watershed } \\
\hline $\mathrm{NH}_{4}+$ assimilation & 75 & & & & & -75 & & & & & \\
\hline $\begin{array}{l}\text { Total Pool composition } \\
\text { (calculated) }\end{array}$ & $-130^{a}$ & 241 & 76 & 32 & 58 & 0 & 82 & 39 & 11 & 15 & (130) \\
\hline $\begin{array}{l}\text { Pool composition } \\
\text { (measured) }\end{array}$ & & 241 & 76 & 33 & 58 & 0 & 82 & 44 & 13 & & \\
\hline
\end{tabular}

${ }^{a}$ ANC $=-\left\{\mathrm{H}^{+}-\mathrm{acy}\right\}+\left\{\mathrm{Org}^{-}\right\}$for titration acid neutralizing capacity. ANC $=-(-130)+130=260 \mu \mathrm{eq} \mathrm{L}^{-1}$ calculated.

ANC $=296$ measured by Gran Titration (total). 
become acidic. If the Emei Mountain precipitation acidity were to increase to 196 $\mu$ eq $\mathrm{L}^{-1}$ from the measured $66 \mu \mathrm{eq} \mathrm{L}^{-1}$ after evapoconcentration in Table IVB, then the calculated Total Pool Composition would result in an ANC of $0.0 \mu \mathrm{eq}$ $\mathrm{L}^{-1}$, when all the neutralizing reactions from ion exchange and weathering are summed in the Table.

\section{Conclusions}

The chemistry of surface waters in southwest China is a result of mixing $\mathrm{H}_{2} \mathrm{SO}_{4}$ from acid deposition and calcium carbonate from dust and weathering reactions with a few other solutes. Reactions that are important include ammonium assimiJation by plants and ion exchange/chemical weathering reactions that produce base cations $\left(\mathrm{Ca}^{2+}, \mathrm{Mg}^{2+}, \mathrm{K}^{+}, \mathrm{Na}^{+}\right)$. The deposition of sulfate is extremely large, and $\mathrm{SO}_{4}{ }^{2-}$ concentrations in precipitation and surface waters are at least two times higher than concentrations reported in similar regions receiving acid deposition around the world, including the 'Black Triangle'of Central Europe and the Czech Republic.

Even the lakes and streams with the lowest ANC concentrations in southwest China are not considered sensitive with respect to acid deposition. Such sensitivity is usually defined as less than $50 \mu \mathrm{eq} \mathrm{L}{ }^{-1}$ ANC (Brakke et al., 1988). Precipitation is acidic in southwest China, but not as acidic as would be expected from the very large sulfate concentrations found there. There exists sufficient ANC (130 ueq $\mathrm{L}^{-1}$ ) even at the high elevation Emei Pool, the most sensitive water sampled, to neutralize runoff and episodes of acidification. We conclude that precipitation acidity is partially neutralized by calcareous dust particles that are scavenged and dissolved by acidic precipitation. If the air were much cleaner in southwest China (lower in TSP concentrations), precipitation acidity would be much greater, as large as $100-150 \mu \mathrm{eq} \mathrm{L}{ }^{-1}$, based on present ion chemistry. This would place southwest Phina among the areas with the most acidic precipitation in the world. Nevertheless, there appears to be considerable acid neutralizing capacities remaining in the watersheds studied. With the possible exception of high elevation lakes and rivers, it is not likely that acidification of surface waters will occur.

\section{Acknowledgements}

We thank Werner Stumm and Laura Sigg for valuable discussions and the Swiss Federal Institute for Water Resources and Water Pollution Control (EAWAG-ETH) for sabbatical support. We also thank K.J. Hsu, ETH, for the geologic description of the region, and principal collaborators in the water quality survey and analysis D. W. Zhao, D. C. Wang, H. X. Tong, F. Z. He, X. L. Meng and Z. W. Feng. H.B.X. received financial support from Academia Sinica, PRC. J.L.S. received financial support from the Center for International Rural and Environmental Health and the Envionmental Health Sciences research Center of NIEHS at the University of lowa. 


\section{References}

Blank, L. W.: 1985, Nature 314, 311.

Blank, L. W., Roberts, T. M., and Skeffington, R. A.: 1988, Nature 336, 27.

Brakke, D. F., Landers, D. H., and Eilers, J. M.: 1998, Environ. Sci. Technol. 22, 155.

Cerney, J.: 1992, Proc. of the Intl. Symp. on Expmntl. Manipulations of Biota and Biogeochemical Cycling (European Community Ecosystem Research Report, Copenhagen).

Eilers, J. M., Brakke, D. F., and Landers, D. H.: 1988a, Environ. Sci. Technol. 22, 164.

Eilers, J. M., Landers, D. H., and Brakke, D. F.: 1988b, Environ. Sci. Technol. 22, 172.

Giovanoli, R., Schnoor, J. L., Sigg, L., Stumm, W., and Zobrist, J.: 1988, Clays and Clay Minerals 36, 521.

Heise, L.: 1988, Worldwatch. 1, 12.

Institute of Environmental Chemistry et al:: 1987, Formation, Effects and Countermeasures of Acid Deposition in Southwest China, Academia Sinica, Beijing, December.

Lee, S. and Schnoor, J. L.: 1988, Environ. Sci. Technol. 22, 190.

Lindberg, S. E., Lovett, G. M., Richter, D. D., and Johnson, D. W.: 1986, Science 231, 141.

Lindberg, S. E. and Garten, C. T., Jr.: 1988, Nature 336, 148.

Moldan, B. and Schnoor, J. L.: 1992, Environ. Sci. Technol. $26,14$.

Morel, F. and Morgan, J.: 1972, Environ. Sci. Technol. 6, 58.

National Academy of Sciences Acid Deposition: 1983, Atmospheric Processes in Eastern North America National Academy Press, Washington, D.C.

Natural Resources Ecology Laboratory: 1986, NADP-NTN Precipitation Chemistry in the United States, Colorado State University, Ft. Collins.

Rubin, E. S., Small, M. J., Bloyd, C. N., and Henrion, M.: 1992, J. Envir. Engrg. 118, 120.

Schnoor, J. L. and Stumm, W.: 1986, Schweiz. Z. Hydrol. 48, 171.

Stumm, W., Sigg, L., and Schnoor, J. L.: 1987, Environ. Sci. Technol. 21, 8.

Ulrich, B., Mayer, R., and Khanna, P. K.: 1979, Deposition von Luftverunreinigungen und ihre Auswirkungen in Walsőkosystemen im Solling, J. D. Sauerländers Verlag, Frankfurt am Main.

van Breeman, N., Burrough, P. A., Velthorst, E. J., van Dobben, H. F., de Wit, J., Ridder, J. B., and Reijnders, H. F. R.: 1982, Nature 299, 548.

Wadden, R. A. and Scheff, P. A.: 1983, Indoor Air Pollution, Wiley, New York.

Wright, R. F.: 1988, Environ. Sci. Technol. 22, 178.

Xue, H. B., Bai, N. B., and Tang, H. X.: 1988, Acta Scienciae Circumstanciae 8, 393. 